\title{
Pengaruh Manajemen Spiritual Leadership dalam Pemerataan Ekonomi Sektor Riil
}

\author{
1* Sumadi, ${ }^{2}$ Yudi siyamto \\ ${ }^{1,2}$ Sekolah Tinggi Ilmu Ekonomi AAS Surakarta, Indonesia \\ *Email korenpondensi: sumadi@ stie-aas.ac.id
}

\begin{abstract}
This study aims to analyze the characteristics of culinary service business leaders in Surakarta, also to analyze the spiritual role of leadership in the growth of the creative economy in Surakarta. This research method is a quantitative method with an explanation approach. There are 5 (five) key informants (informants) who will be interviewed in this study consisting of leaders in the culinary service sector business in Surakarta. The results of data analysis research obtained that the results obtained that the variable vision, hopel faith, altruistic love, meaning / calling, membership, commitment and job satisfaction have a significant positive influence on spiritual leadership.
\end{abstract}

Keywords: Spiritual Leadership, creative economy, culinary services sector

\begin{abstract}
Abstrak
Penelitian ini bertujuan untuk menganalisis karakteristik pemimpin bisnis jasa kuliner di Surakarta, juga untuk menganalisis peran spiritual kepemimpinan dalam pertumbuhan ekonomi kreatif di Surakarta. Metode penelitian ini adalah metode kuantitatif dengan pendekatan penjelasan. Ada 5 (lima) informan kunci (informan) yang akan diwawancarai dalam penelitian ini yang terdiri dari para pemimpin di bisnis sektor jasa kuliner di Surakarta. Hasil penelitian analisis data diperoleh bahwa hasil yang diperoleh bahwa variabel visi, harapan / iman, cinta altruistik, makna / panggilan, keanggotaan, komitmen dan kepuasan kerja memiliki pengaruh positif signifikan terhadap kepemimpinan spiritual.
\end{abstract}

Kata kunci: Jakarta Islamic Index, Nilai tukar rupiah, Suku bunga SBI, inflasi

Saran sitasi: Sumadi \& Siyamto, Y. (2019). Pengaruh Manajemen Spiritual Leadership dalam Pemerataan Ekonomi Sektor Riil Index. Jurnal Ilmiah Ekonomi Islam, 5(01), 35-41. doi: http://dx.doi.org/10.29040/jiei.v4i03.341

DOI: http://dx.doi.org/10.29040/jiei.v4i03.341

\section{Pendahuluan}

Masih banyak orang yang hidup di negara berkembang berupaya berjuang untuk keluar dari kemiskinan, kurangnya fasilitas kesehatan yang memadai, tidak terjaminnya makanan dan minuman yang sehat, kurang amannya lingkungan rumah, hambatan keuangan untuk pendidikan dan lain sebagainya. Pada era kompetisi yang semakin tajam kebutuhan untuk perubahan organisasi telah dianggap penting lebih dari sebelumnya. Sebagai pemimpinan di sebuah organisasi yang mempunyai program pengentasan kemiskinan tentu memerlukan model gaya kepempinan dan perencanaan strategis tertentu (Oliphant, 2016). kepemimpinan organisasi dianggap sebagai 
tokoh dalam perubahan organisasi.Perilaku pemimpin yang kurang baikakhir-akhir ini menimbulkan terjadinya krisiskepercayaan terhadap pemimpin (Astuti, 2013). Pemimpin yang seharusnya menjadi pelindung, pengarah dan memotivasi bawahan sekarang ini menjadi baranglangka. Manajemen dan kepemimpinan yang baik dapat mempengaruhi pelayanan publik, maksudnya seorang pemimpin yang baik bisa memberi contoh pada bawahan bagaimana melayani publik dengan baik. Disamping itu Pemimpin juga memiliki kedudukan yang sangat penting dalam organisasi, Keberhasilan organisasi dalam mencapai kinerja tinggi sangat tergantung pada pimpinan (Siswanto, 2002).

Seorang dikatakanmampu ketika dia memiliki kepribadian (personality), kemampuan (ability) dan kesanggupan (capability) (Wahyusumidjo, 1987). Fry (2003) menyatakan bahwa kepemimpinan spiritual menciptakan motivasi intrinsik melalui visi, harapan / iman, dan cinta altruistik, yang mengarah ke kelangsungan hidup spiritual melalui makna / panggilan dan keanggotaan.

Teori kepemimpinan spiritual adalah teori kepemimpinan yang dirancang untuk menciptakan motivasi intrinsik. Kepemimpinan spiritual terdiri dari nilai, sikap dan perilaku untuk memotivasi diri sendiri dan orang lain untuk memiliki rasa spiritual dalam hidupnya melalui keterpanggilan dan keanggotaan, memiliki makna dalam hidup mereka, merasa dimengerti dan dihargai. Mereka merasa mengalami kehidupan yang berarti.Teori Kepemimpinan Spiritual dikembangkan dalam model motivasi intrinsik yang mengembangkan visi, harapan/keyakinan dan cinta altruistik.Tujuan kepemimpiananSpiritual untuk memenuhi kebutuhan mendasar dari pemimpin dan pengikut untuk kelangsungan hidup spiritual melalui keterpanggilan dan keanggotaan. Hal ini memerlukan: pertama ciptakan visi dimana pemimpin dan pengikut mengalami rasa keterpanggilan, kedua membangun budaya sosial, berdasarkan nilai cinta altruistik dimana pemimpin dan pengikut memiliki rasa keanggotaan, merasa dimengerti dan dihargai (Fry, 2003).
Pemimpin dan karyawan merupakan bagian dari proses pengembangan Sumber Daya Manusia (SDM), dimana SDM merupakan asset dari sebuah organisasi atau perusahaan yang apabila dikelola secara tepat maka akan memberikan nilai tambah bagi perusahaannya. Dan pemimpin memegang peran kunci dalam memformasikan strategi organisasi, sehingga peranannya akan memengaruhi keberhasilan organisasi, sehingga perlu adanya hubungan manusiawi yang baik agar setiap arahan yang diberikan dapat dilakukan dengan baik oleh karyawannya (Rahman, 2011).

Seorang pemimpin yang beragama Islam berkewajiban meneladani Rasulullah, karena seluruh sikap, tingkah laku dalam memimpin umat Islam pada dasarnya merupakan pancaran isi kandungan Al-Qur'an. Di samping itu, Allah juga mengaruniakan kepada manusia suatu pedoman yang lengkap dalam bentuk Al-Qur'an. Salah satu fungsinya adalah sebagai Al-Furqon, dimana didalamnya kebaikan dan keburukan (Maghfiroh, 2012). Suatu lembaga pasti dibutuhkan seorang pemimpin yang diharapkan mampu melayani serta menolong orang lain untuk maju dengan ikhlas yang sesuai dengan ciri-ciri kepemimpinan Islam. Kepemimpinan adalah suatu hubungan antar individu yang mempengaruhi orang lain agar mereka mau bekerja ke arah pencapaian sasaran tertentu (Winardi, 1990). Kepemimpinan menurut Islam yaitu musyawarah, adil dan kebebasan berfikir. Melalui musyawarah proses pembuatan keputusan dapat dicapai. Dalam musyawarah semua pihak dapat berperan untuk memutuskan, tidak hanya pemimpin yang berkuasa disini. Seorang pemimpin juga harus bertindak adil tidak memihak siapapun yang benar harus dibela dan yang salah harus diberi sanksi. Prinsip yang terakhir adalah seorang pemimpin juga harus memberikan kebebasan berfikir kepada anggotanya, memberikan kesempatan untuk mengemukakan pendapatnya. Sehingga karyawan merasa dihargai keberadaannya (Rivai, 2006). 


\section{Teori Spiritual Leadership Fry}

Fry (2003) mengembangkan konsep kepemimpinan spiritual mengingat tantangan lingkungan organisasional abad 21 yang sarat dengan perubahan dan memerlukan organisasiorganisasi pembelajar (Learning Organizations) yang adaptif (Fry, 2003). Organisasi-organisasi pembelajar mengutamakan respon yang cepat dengan tanggung jawab yang tinggi, produktif, memotivasi para pekerja secara instrinsik (selfdirected), memberdayakn tim secara fleksibel, struktur yang datang (flat), pengembangan jaringan kerja, berbeda dan global.

Pangilan (Calling), Menciptakan visi dimana anggota organisasi merasakan panggilan dalam diri mereka bahwa hidup mereka memiliki makna tertinggi dan bias membuat perbedaan yang berarti didalamnya. Keanggotaan (Membership), Membentuk budaya organisasi/ sosial berdasar pada cinta sesama, yaitu saat pemimpin dan bawahan saling peduli, perhatian, dan menghargai diri sendiri dan orang lain, sehingga mereka mampu menghasilkan rasa menjadi bagian dari organisasi secara bersamasama dan saling memahami serta menghormati satu sama lain (Fry,2003). Spiritual leadership memerlukan: (1) penciptaan visi dimana para anggota organisasi mengalami panggilan hidup dalam hal kehidupan mereka, (2) mengembangkan suatu budaya sosial berdasarkan pada cinta altruistik dimana pemimpin dan pengikut mempunyai perawatan, perhatian dan apresiasi asli untuk diri sendiri dan orang lain, memproduksi rasa keanggotaan dan merasa dipahami dan dihargai.

Fry (2003) menegaskan bahwa pemimpin bertanggung jawab menyusun visi, tujuan misi, strategi dan implementasinya. Dalam menyusun visi, ia juga bertanggung jawab menciptakan kesesuaian nilai antar semua level dalam organisasi dengan semua pemangku kepentingan (stakeholders). Fry menjelaskan bahwa kepemimpinan spiritual melalui visi, harapan/ keyakinan, dan cinta altruistik memberikan dasar motivasi instrinsik melalui keterlibatan dalam tugas dan identifikasi terhadap tujuan. Hal ini sesuai dengan teori motiviasi intrinsik "self
Dedeterminism"Ryan R.M dan Decy E.L(2000); Ryan (2004) yang mengemukakan tiga inti kebutuhan tingkat tinggi pada individu, yang merupakan dasar bagi motivasi diri dan integrasi kepribadian, yaitu kompetensi, keterhubungan (relatedness), dan otonomi.

Menurut Fry(2003), kepemimpinan spiritual dapat dipandang sebagai sesuatu yang perlu untuk sukses organisasi dalam lingkungan saat ini yang tak dapat diramalkan, yang digerakkan oleh internet. Orang-orang membutuhkan sesuatu yang dapat dipercaya, seseorang ytang dapat dipercaya, dan orang-orang yang dapat percaya kepadanya. Seorang pemimpin spiritual adalah orang yang berjalan dimuka disaat seseorang membutuhkan orang untuk diikuti (sesuai kompoen visi), berjalan dibelakang ketika seseorang membutuhkan dorongan (sesuai komponen harapan/keyakinan), dan berjalan disamping saat seseorang membutuhkan teman/ sahabat (sesuai cinta altruistik). Pemimpin spiritual memimpin melalui diskursus intelektual dan dialog, dan keyakinan bahwa bila orangorang dilibatkan dan mendapat informasi yang tepat, dapat membuat keputusan intelektual dan bertanggung jawab atas keputusan tersebut yang mempengaruhi hidupnya (Widyarini, 2010).

Pada intinya konsep spiritual leadership adalah kepemimpinan yang membawa dimensi keduniawian kepada dimensi spiritual. Tuhan adalah pemimpin sejati yang mengilhami segala bentuk perbuatan, mempengaruhi dan menggerakan hati nurani hamba-Nya dengan cara yang sangat bijak melalui keteladanan, karena itu kepemimpinan spiritual disebut juga sebagai kepemimpinan yang berdasar etikareligius (Tobroni, 2010).

Reave (2005) menyebutkan bahwa tingkah laku spiritual leadership termasuk menghormati orang lain, kesetaraan, kepedulian, identifikasi dengan kontribusi, reaksi untuk umpan balik dan refleksi diri. Hal tersebut dapat terjadi karena adanya faktor pemimpin yang melayani. Melayani memiliki makna semangat batin untuk membantu orang lain, menjaga kepercayaan serta mampu menjadi pendengar yang baik. 


\section{Jurnal Ilmiah Ekonomi Islam, 5(01), 2019, 38}

\section{Metode Penelitian}

Jenis penelitian ini merupakan penelitian kuantitatif, dengan pendekatan penjelasan (explanation reseach). Penelitian penjelasan (explanation reseach) merupakan jenis penelitian dimana peneliti menjelaskan hubungan kausal antara variabel-variabel melalui pengujian hipotesis, yaitu menguji hipotesis-hipotesis berdasarkan teori yang telah dirumuskan sebelumnya dan kemudian data yang telah diperoleh dihitung lebih lanjut melalui pendekatan kuantitatif (Sugiyono, 2009). Penelitian ini didasarkan pada pendekatan kuantitatif yang melibatkan distribusi kuesioner dan analisis data menggunakan SPSS. SPSS adalah paket perangkat lunak yang digunakan untuk melakukan berbagai jenis uji statistik (Coakes, S. J., \& Steed, 2009).

Penggalian informasi karakteristik spiritual menggunakan masing-masing 5 narasumber dari usaha kuliner di Surakarta (Owner Bakso Kadipolo, Owner Mie Angglo, Owner Soto Shubuh, Owner Sate Kambing Pak Pur, dan Owner Kepala Ikan Mas Agus). Sedangkan Populasi penelitian ini adalah para pegawai di usaha kuliner tersebut. Sampel merupakan sekumpulan dari sebagian anggota obyek yang diteliti (Sugiyono, 2009). Teknik pengambilan sampel yang digunakan dalam penelitian ini adalah purposive sampling, purposive sampling adalah teknik penentuan sampel dengan pertimbangan tertentu (Sugiyono, 2009). Kriteria yang digunakan pada penelitian ini adalah pegawai tetap yang masa kerjanya diatas satu tahun, dengan alasan pegawai tetap yang telah memiliki masa kerja diatas satu tahun telah memiliki pengalaman yang cukup tentang apa yang terjadi dalam lingkungan usaha kuliner tersebut dengan masing-masing tempat berjumlah jumlah 10 pegawai.

Teknis analisis data yang digunakan dalam penelitian ini yaitu menggunakan regresi linear berganda dengan persamaan, sebagai berikut $\mathrm{Y}=\mathrm{a}+\mathrm{b}_{1} \mathrm{X}_{1}+\mathrm{b}_{2} \mathrm{X}_{2}+\mathrm{b}_{3} \mathrm{X}_{3}+\mathrm{b}_{4} \mathrm{X}_{4}+\mathrm{b}_{5} \mathrm{X}_{5}+\mathrm{b}_{6} \mathrm{X}_{6}+\mathrm{b}_{7} \mathrm{X}_{7}+\mathrm{e}$.
Keterangan:

$\mathrm{Y}=$ spritual leadership.

a $=$ Harga konstanta

$\mathrm{b}_{1,2,3}=$ Harga koefisien regresi

$\mathrm{X}_{1}=$ Visi

$\mathrm{X}_{2}=$ Harapan / Iman

$\mathrm{X}_{3}=$ Cinta Altruistik

$\mathrm{X}_{4}=$ Makna / Panggilan

$\mathrm{X}_{5}=$ Keanggotaan

$\mathrm{X}_{6}=$ Komitmen

$\mathrm{X}_{7}=$ Kepuasan Kerja

$\mathrm{e} \quad=$ standard error

\section{Hasil dan Pembahasan}

\subsection{Hasil Penelitian}

Dari uji validitas dan reliabilitas, semua variabel valid dan reliable.Hasil ini untuk mengukur seberapa besar pengaruhnya antara variabel independen terhadap dependennya yang disajikan dalam model ekonometrika.Hasil ini sebagai tindak lanjut dari hasil pengujian kelayakan data yang dilakukan. Dengan menggunakan SPSS 16 maka dapat dihasilkan sebagai berikut:

Tabel I Hasil Uji Regresi Linier Berganda

\begin{tabular}{llll}
\hline \multirow{4}{*}{ Variabel } & $\begin{array}{l}\text { Unstandardized } \\
\text { coefficients } \\
\end{array}$ & $\mathrm{T}$ & $\mathrm{S}$ Sig \\
& $\mathrm{B}$ & & \\
\hline (Constant) & 1,686 & 0,047 & 0,963 \\
Visi & 0,085 & 2,221 & 0,030 \\
Harapan / Iman & 0,068 & 2,064 & 0,043 \\
Cinta Altruistik & 0,055 & 2,031 & 0,046 \\
Makna / & 0,109 & 3,219 & 0,002 \\
Panggilan & 0,092 & 2,182 & 0,033 \\
Keanggotaan & 0,046 & 2,424 & 0,018 \\
Komitmen & 0,043 & 2,420 & 0,018 \\
Kepuasan & & & \\
Kerja & & & \\
\hline
\end{tabular}

Dari hasil analisis regresi berganda pada table I diatas, dapatdiperoleh persamaan sebagai berikut:

$$
\begin{gathered}
Y=1,686+0,085 \mathrm{X}_{1}+0,068 \mathrm{X}_{2}+0,055 \mathrm{X}_{3}+0,109 \mathrm{X}_{4}+ \\
0,092 \mathrm{X}_{5}+0,046 \mathrm{X}_{6}+0,043 \mathrm{X}_{7}
\end{gathered}
$$

\subsection{Pembahasan}

Hipotesis pertama yang diajukan dalam penelitian ini adalah visi berpengaruh secara signifikan terhadap spiritual leadership. 
Berdasarkan pada hasil analisis yang dilakukan, Hasil yang diperoleh dari uji t untuk variabel visi menunjukkan nilai t-hitung sebesar 2,221 dengan nilai signifikan sebesar 0,030 berarti lebih kecil dari 0,05 , sedangkan t-tabel dengan taraf signifikan 0,05 diperoleh nilai sebesar 1,66515. Dikarenakan t-hitung lebih besar dari t-tabel (2,221> 1,66515), maka H1 diterima. Artinya bahwa variabel visi berpengaruh signifikan terhadap spiritual leadership. Hasil ini sesuai dengan penelitian yang dilakukan oleh Pujiastuti (2014).

Hipotesis kedua yang diajukan dalam penelitian ini adalah Harapan / imanberpengaruh secara signifikan terhadap spiritual leadership. Hasil yang diperoleh dari uji t untuk variabel harapan/iman menunjukkan nilai t-hitung sebesar 2,064 dengan nilai signifikan sebesar 0,043 berarti lebih kecil dari 0,05 , sedangkan t-tabel dengan taraf signifikan 0,05 diperoleh nilai sebesar 1,66515. Dikarenakan t-hitung lebih besar dari t-tabel $(2,064>1,66515)$, maka H2 diterima. Artinya bahwa variabel harapan/iman berpengaruh signifikan terhadap spiritual leadehrship. Hasil ini sesuai dengan penelitian yang dilakukan oleh (Azlimin, 2015).

Hipotesis ketiga yang diajukan dalam penelitian ini adalah cinta altruistik berpengaruh secara signifikan terhadap spiritual leadership. Hasil yang diperoleh dari uji t untuk variabel cinta altruistik menunjukkan nilai t-hitung sebesar 2,031 dengan nilai signifikan sebesar 0,046 berarti lebih kecil dari 0,05 , sedangkan $\mathrm{t}$ tabel dengan taraf signifikan 0,05 diperoleh nilai sebesar 1,66515. Dikarenakan t-hitung lebih besar dari t-tabel $(2,031>1.66515)$, maka H3 diterima. Artinya bahwa variabel cinta altruistic berpengaruh signifikan terhadap spiritual leadership. Hasil dari penelitian ini sesuai dengan penelitian yang dilakukan pada perangkat desa Kabupaten Banyumas oleh Pujiastuti (2014).

Hipotesis keempat yang diajukan dalam penelitian ini adalah makna/panggilan berpengaruh secara signifikan terhadap spiritual leadership. Hasil yang diperoleh dari uji t untuk variabel makna/panggilan menunjukkan nilai t- hitung sebesar 3,219 dengan nilai signifikan sebesar 0,002 berarti lebih kecil dari 0,05, sedangkan t-tabel dengan taraf signifikan 0,05 diperoleh nilai sebesar 1.66515. Dikarenakan thitung lebih besar dari t-tabel (3,219> 1,66515), maka H4 diterima. Artinya bahwa variabel makna/panggilan berpengaruh signifikan terhadap spiritual leadership. Hasil dari penelitian ini sesuai dengan penelitian yang dilakukan Fii Ahsani (2013) dengan judul pengaruh kepemimpinan spiritual pada manajemen karir dan kepuasan kerja karyawan.

Hipotesis kelima yang diajukan dalam penelitian ini adalah keanggotaan berpengaruh secara signifikan terhadap spiritual leadership. Hasil yang diperoleh dari uji t untuk variabel keanggotaan menunjukkan nilai t-hitung sebesar 2,182 dengan nilai signifikan sebesar 0,033 berarti lebih kecil dari 0,05 , sedangkan t-tabel dengan taraf signifikan 0,05 diperoleh nilai sebesar 1,66515. Dikarenakan t-hitung lebih besar dari t-tabel (2,182 > 1,66515), maka H5 diterima. Artinya bahwa variabel keanggotaan berpengaruh signifikan terhadap spiritual leadership. Hasil penelitian ini sesuai dengan penelitian sebelumnya yang dilakukan Ahsani (2010)pada Pegawai Negeri Sipil Pemerintah Kabupaten Sukoharjo.

Hipotesis keenamyang diajukan dalam penelitian ini adalah komitmen berpengaruh secara signifikan terhadap spiritual leadership. Hasil yang diperoleh dari uji t untuk variabel komitmen menunjukkan nilai t-hitung sebesar 2,424 dengan nilai signifikan sebesar 0,018 berarti lebih kecil dari 0,05 , sedangkan t-tabel dengan taraf signifikan 0,05 diperoleh nilai sebesar 1,66515. Dikarenakan t-hitung lebih besar dari t-tabel $(2,424>1.66515)$, maka H6 diterima.Artinya bahwa variabel komitmen berpengaruh signifikan terhadap spiritual leadership. Hasil ini sesuai dengan penelitian yang dilakukan oleh Fry, L.W.; Steve, Vitucci.;Marie, (2005); Nurfika A (2009)yang mengatakan bahwa komitmen berpengaruh signifikan terhadap spiritual leadership. 
Sedangkan hipotesis ketujuhyang diajukan dalam penelitian ini adalah Kepuasan kerja berpengaruh secara signifikan terhadap spiritual leadership. Hasil yang diperoleh dari uji t untuk variabel kepuasan kerja menunjukkan nilai thitung sebesar 2,420 dengan nilai signifikan sebesar 0,018 berarti lebih kecil dari 0,05, sedangkan t-tabel dengan taraf signifikan 0,05 diperoleh nilai sebesar 1.66515. Dikarenakan thitung lebih besar dari t-tabel $(2,420>1.66515)$, maka H7 diterima.Artinya bahwa variabel kepuasan kerja berpengaruh signifikan terhadap spiritual leadership. Hasil penelitian ini sesuai dengan penelitian yang dilakukan (Fii Ahsani, 2013; L. . Fry et al., 2005; Junita \& Sutanto, 2015)

\section{Kesimpulan}

Berdasarkan hasil analisis maka dapat disimpulkan bahwa Pertama, Visi berpengaruh signifikan terhadap spiritual leadership.Kedua, Harapan / imanberpengaruh signifikan terhadap spiritual leadership.Ketiga, Cinta altruistik berpengaruh signifikan terhadap spiritual leadership.Keempat, Makna / panggilan berpengaruh secara signifikan terhadap spiritual leadership.Kelima, Keanggotaan berpengaruh signifikan terhadap spiritual leadership.Keenam, Komitmen berpengaruh signifikan terhadap spiritual leadership.Ketujuh, Kepuasan kerja berpengaruh signifikan terhadap spiritual leadership.

\section{Ucapan Terimakasih}

Terimakasih kami haturkan kepada Kemenristekdikti yang telah memberikan hibah dalam penelitianini, terimakasih juga kami sampaikan kepada LPPM STIE AAS Surakarta yang telah memsupport atas terlaksananya penelitian ini.

\section{Daftar Pustaka}

Altaf, N. (2016).Economic value added or earnings: What explains marketvalue in Indian firms".Future Business Journal 2 152-166, Productionand Hosting by Elsevier

Azlimin, A. H. (2015). Model Peningkatan Komitmen Sumber Daya Manusia Berbasis Spiritual Leadership Dan Spiritual Survival Serta Workplace Spirituality Dengan Moderating Individual Spirituality. 2nd Conference in Business, Accounting and Management, Universitas Islam Sultan Agung, 2 No 1.

Astuti, R. P. (2013). Spiritual Intellegance: Tinjauan Teoritis Dan Pembentuk Karakter Spiritual Leadership. Universitas Wijayakusuma Purwokerto.

Brigham,E.F., \& Joel F. H. (2010).Dasar-Dasar ManajemenKeuangan. Buku 1, Edisi 11. Jakarta: Salemba Empat:

Brigham,E.F., \& Joel F. H. (2010).Dasar-Dasar Manajemen Keuangan. Buku 2, Edisi 11. Jakarta: Salemba Empat.

Coakes, S. J., \& Steed, L. (2009). SPSS: Analysis without anguish using SPSS version 14.0 for Windows, John Wiley \& Sons, Inc.

Endri,(2008).“Analisis Kinerja Keuangan Dengan Menggunakan RasioRasioKeuangan Dan Economic Value Added (Studi Kasus: PT. Bank Syariah Mandiri)",TAZKIA Islamic Finance \& Business, Vol. 3 No.2.

Fahmi, I. (2011).Analisis Laporan Keuangan. Alfabeta, Bandung.

Fii Ahsani, R. (2013). Pengaruh kepemimpinan spiritual pada manajemen karir dan produktifitas karyawan.

Fry. (2003). "Toward a Theory of Spiritual Leadership" dalam The Leadership Quarterly, Volume 14.

Fry, L. W., Hannah, S. T., Michael, N., \& Fred, O. W. (2011). Impact of spiritual leadership on unit performance. The Leadership Quarterly, 259-270. http://dx.doi.org/10.1016/j.leaqua.2011.02.0 02 . 
Fry, L.W.; Steve, Vitucci.;Marie, C. (2005). spiritual leadership and army transformation: theory, Measursures, and establishing a baseline. Leadership Quartency Greewich Vol 16. Iss 5.

Fry, L., \& Nisiewicz, M. (2013). Maximizing the triple bottom line through spiritual leadership. Stanford: Stanford University Press.

Haryono, S. (2009).Analisis Laporan Keuangan Perbankan Syariah. Cetakan Pertama, Pustaka Sayid Sabiq, Indramayu.

Hasan,M. I.(2002).Pokok-Pokok Materi Metodologi Penelitian dan Aplikasinya. Cetakan Pertama, Ghalia Indonesia, Jakarta.

Jakub,S., Bartosova V. \& Kicova E. (2015). Economic Value Added asa measurement tool of financial performance, Procedia Economics and Finance 26 (2015) 484 - 489, Published by Elsevier B.V. This is an open access article under the CC BY-NC-ND

Keown,A.

(2010).ManajemenKeuangan:Principlesand Applications, Tenth Edition. Jakarta: PT INDEKS.

Muhammad, (2008).Metodologi Penelitian Ekonomi Islam Pendekatan Kuantitatif.. PT. Raja Grafindo, Jakarta.

Pujiastuti, R. (2014). Karakteristik Spiritual Leadership Perangkat Desa Di Kabupaten Banyumas (Berdasar Teori Spiritual Leadership Fry). Seminar Nasional dan Call for Paper (Sancall 2014): Research Methods And Organizational Studies.

Putra, A. W., Dzulkirom A.R.M.\& Saifi, M. (2015). Evaluasi Rasio Keuangan Dan Metode Economic Value Added (EVA) Guna Penilaian Kinerja Keuangan Perusahaan (Studi Pada PT. Hm. Sampoerna, tbk dan PT. Gudang Garam, tbk yang Terdaftar di Bursa Efek Indonesia Periode tahun 2011- 2013)". Jurnal Administrasi Bisnis (JAB), Vol. 28 No. 1
Reave, L. (2005). Spiritual values and practices related to leadership effectiveness.

Sahara,B. H:,Rahayu; S: M ZahrohZ.A. (2015). Analisis Kinerja Keuangan Perusahaan Dengan Menggunakan Rasio Keuangan Dan Metode Economic Value Added (EVA) (Studi pada PT. Semen Indonesia (Persero) Tbk periode 2011-2013). Jurnal Administrasi Bisnis (JAB), Vol. 2No. 1

Siswanto, B. (2002). Manajemen Tenaga Kerja Indonesia Pendekatan Administratif dan Operasional. Jakarta: Bumu aksara.

Sugiyono. (2009). Metode Penelitian Bisnis (Pendekatan Kuantitatif, Kualitatif, dan R\&D). Bandung: CV Alfabeta.

Wahyusumidjo. (1987). Kepemimpinan dan Motivasi. jakarta: Ghalia.

Widyarini, N. M. . (2010). Kepemimpinan Spiritual untuk Indonesia (Mengungkap konsep kepemimpinan spiritual dari Fry dengan kepemimpinan nusantara yang etisuniversal). Jurnal Paramadina Edisi Khusus, 7 No 2.

Tobroni. (2010). Spiritual Leadership, The Problem Solver Krisis Kepemimpinan Dalam Pendidikan Islam.

Usman, H., \& Akbar, S. (2003). Purnomo, Metodologi Penelitian Sosial Cet. IV. 